\title{
Ecosystem carbon emissions from 2015 forest fires in interior Alaska
}

\author{
Christopher Potter
}

\begin{abstract}
Background: In the summer of 2015, hundreds of wildfires burned across the state of Alaska, and consumed more than 1.6 million ha of boreal forest and wetlands in the Yukon-Koyukuk region. Mapping of 113 large wildfires using Landsat satellite images from before and after 2015 indicated that nearly $60 \%$ of this area was burned at moderateto-high severity levels. Field measurements near the town of Tanana on the Yukon River were carried out in July of 2017 in both unburned and 2015 burned forested areas (nearly adjacent to one-another) to visually verify locations of different Landsat burn severity classes (low, moderate, or high; LBS, MBS, HBS).

Results: Field measurements indicated that the loss of surface organic layers in boreal ecosystem fires is a major factor determining post-fire soil temperature changes, depth of thawing, and carbon losses from the mineral topsoil layer. Measurements in forest sites showed that soil temperature profiles to $30 \mathrm{~cm}$ depth at burned forest sites were higher by an average of $8-10^{\circ} \mathrm{C}$ compared to unburned forest sites. Sampling and laboratory analysis indicated a $65 \%$ reduction in soil carbon content and a 58\% reduction in soil nitrogen content in severely burned sample sites compared to soil mineral samples from nearby unburned spruce forests.

Conclusions: Combined with nearly unprecedented forest areas severely burned in the Interior region of Alaska in 2015, total ecosystem fire-related losses of carbon to the atmosphere exceeded most previous estimates for the state, owing mainly to inclusion of potential "mass wasting" and decomposition in the mineral soil carbon layer in the 2 years following these forest fires.
\end{abstract}

Keywords: Wildfire, Carbon emission, Alaska, Boreal forest, Soil carbon, Landsat

\section{Background}

The 2015 fire season in Alaska resulted in the second highest acreage burned for the state in a single year. In mid-June 2015, nearly 300 fire starts were reported within 1 week, a consequence of over 61,000 detected lightning strikes during the period [2]. As of mid-September, a total of 2.1 million ha ( 5 million acres) had burned statewide in over 700 separate wildfires. A relatively low snowpack across southern Alaska, compounded by a warm, dry spring, resulted in extremely burnable fuels [2]. Following one of the wettest summers on record in 2014, Alaska's intense fire season of 2015 was extreme by most historical standards.

*Correspondence: chris.potter@nasa.gov

NASA Ames Research Center, Moffett Field, Mountain View, CA, USA
Over the past 50 years, there has been an increase in the frequency and severity of boreal forest wildfires in Alaska [17]. During the 2000s, an average of 767,000 ha per year were burned statewide, $50 \%$ higher than in any previous decade since the 1940s. Deeper burning of surface organic layers in black spruce (Picea mariana (Mill.) BSP) forests has occurred during late growing-season fires and on more well-drained sites [19].

Simulation modeling studies of carbon storage for the state of Alaska have estimated that terrestrial ecosystems have been a net carbon sink (from the atmosphere) of between 5 and $12 \mathrm{Tg} C\left(1 \mathrm{Tg}=10^{12} \mathrm{~g}\right.$ year $^{-1}$ in the 1980s, and between 0 and $10 \mathrm{Tg} \mathrm{C}$ year $^{-1}$ during the 1990s and 2000s [6, 34, 35]. Such a wide range of estimates for ecosystem carbon balance in Alaska has resulted, in part, from large uncertainties in region-wide wildfire emissions of carbon, which have been reported 
over a range of $14-81 \mathrm{Tg} \mathrm{C}$ year $^{-1}$ (Table 1 ). The majority of previous carbon emission studies for Alaska to date have relied on measurements of aboveground (tree) biomass and changes in surface organic layer carbon pools, while generally not including changes in mineral topsoil carbon pools after large-scale burning of the surface layers at moderate and high severity levels.

The objectives of this study were to (1) conduct field validation and statistical comparisons of the burned index rankings of 2015 wildfire areas near Tanana, Alaska to Landsat burn severity classes mapped (postfires) in 2015 and 2016, and (2) estimate total ecosystem (live biomass and mineral topsoil) carbon emissions from the 2015 wildfires across the Yukon-Koyukuk forest region. This work was undertaken as a contribution to the NASA Arctic Boreal Vulnerability Experiment (ABoVE) field campaign, chiefly to better understand changes in related hydrologic and biogeochemical mechanisms in the years following boreal forest wildfires. One of the major questions being addressed by ABoVE is "What processes are controlling changes in boreal-arctic land cover properties and what are the impacts of these changes?".

\section{Methods}

\section{Study area}

The area studied was boreal forest of the Yukon-Koyukuk region of Alaska (Fig. 1). Field measurements were carried out in forests of various states of disturbance from 2015 wildfires surrounding the confluence of the Yukon and Tanana Rivers (near $65^{\circ} 8^{\prime} \mathrm{N}$ latitude, $152^{\circ} 27^{\prime} \mathrm{W}$ longitude), about $200 \mathrm{~km}$ west of Fairbanks, Alaska. Mean annual temperature over much of Interior Alaska is well below freezing, which accounts for a permafrost distribution that is commonly continuous, except in the southern portion of the region [8]. The climate near Tanana is

Table 1 Previous estimates of regional carbon emissions from forest fires in Interior Alaska

\begin{tabular}{|c|c|c|c|c|}
\hline Region & Year(s) & $\operatorname{Tg} C$ year $^{-1}$ & Error $( \pm)$ & References \\
\hline Yukon River Basin, Alaska & 2004 & 81 & 13.6 & Tan et al. [26] \\
\hline Alaska boreal forests & 2000-2009 & 14 & 0.6 & Turetsky et al. [28] \\
\hline Alaska boreal forests & 2004 & 69 & & Veraverbeke et al. [31] \\
\hline Alaska boreal forests and wetlands & 1950-2009 & 39 & & McGuire et al. [23] \\
\hline
\end{tabular}

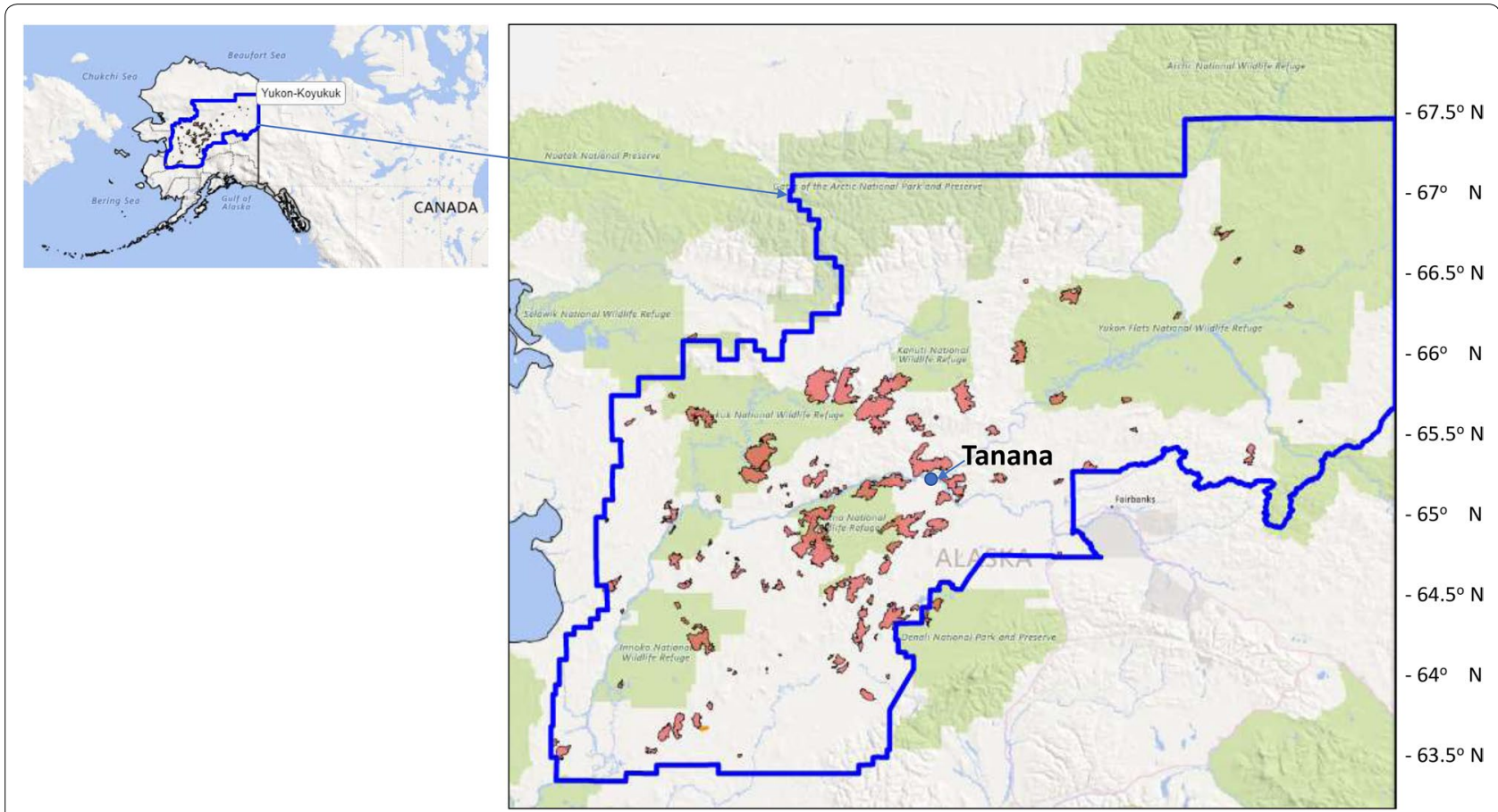

Fig. 1 Wildfires from 2015 analyzed for Landsat RdNBR classes in the Yukon-Kukukuk region of Alaska from the MTBS 
characterized by mean monthly temperature variations between -27 and $22{ }^{\circ} \mathrm{C}$, and a mean annual precipitation total of $29 \mathrm{~cm}, 11 \mathrm{~cm}$ of which falls as snow (data available online at http://www.usclimatedata.com).

Forests in the study area are predominately black spruce on wetter soils and white spruce (Picea glauca) on drier soils, described by [33] as follows: Open black spruce forest description-Total arboreal cover is between 25 and 60\%. Paper birch (Betula papyrifera) may be present in small amounts. The trees tend to be small; the largest trees are about $5-10 \mathrm{~cm}$ in diameter and 6-10 m tall. A well-developed tall shrub layer dominated by dwarf birch (Betula glandulosa) 1-2 m high often is present. Other tall shrubs locally important on moist sites include Alnus crispa, A. sinuata, Salix spp., and Rosa acicularis. A low shrub layer usually is present and consists primarily of some combination of Vaccinium uliginosum, V. vitis-idaea, Potentilla fruticosa, Arctostaphylos rubra, Empetrum nigrum, and Ledum spp. The moss layer is continuous or nearly so and dominated by a combination of Hylocomium splendens, Pleurozium schreberi, Polytrichum spp., and Dicranum spp. Lichens such as Cladonia spp. are important on some sites.

Closed white spruce forest description-the closed white spruce forest type represents the best developed, most productive forests in Alaska. The over-story canopy cover, usually entirely white spruce but occasionally with either scattered paper birch or balsam poplar (Populus balsamifera) can range from 60 to $100 \%$. On the best sites, trees reach $30 \mathrm{~m}$ in height. A well-developed moss layer consisting primarily of the feathermosses Hylocomium splendens, Pleurozium schreberi, and less commonly, Rhytidialdelphus triquetrus is characteristic of these stands. Herbaceous growth is usually sparse but horsetails, primarily Equisetum sylvaticum and E. arvense, may provide as much as $50 \%$ cover in flood-plain stands. Other forbs include Pyrola spp., Linnaea borealis, Geocaulon lividum, Mertensia paniculata, and Goodyera repens.

The Soil Survey for the Upper Tanana Area (USDA, 1999) described the soil types most representative of our study sites, namely Goldstream peat on $0-3 \%$ slopes, alluvial plains, and moraines. These soils are further characterized in this survey as having an organic surface mat $20-40 \mathrm{~cm}$ thick, on top of a dark gray silt loam $15-30 \mathrm{~cm}$ deep. These soils are very poorly drained, with permafrost as the root-restricting feature at $25-50 \mathrm{~cm}$ depth.

\section{Landsat burn severity classes}

Digital maps of burn severity classes at $30-\mathrm{m}$ spatial resolution for wildfires in 2015 across the Yukon-Koyukuk region of Alaska were obtained from the Monitoring Trends in Burn Severity (MTBS) project, which has consistently mapped fires greater than 1000 acres across the United States from 1984 to the present [9]. MTBS is conducted through a partnership between the U.S. Geological Survey (USGS) National Center for Earth Resources Observation and Science (EROS) and the USDA Forest Service.

The normalized burn ratio (NBR) index was first calculated using approximately one-year pre-fire and post-fire images from the near infrared (NIR) and shortwave infrared (SWIR) bands of the Landsat sensors.

$$
\mathrm{NBR}=(\mathrm{NIR}-\mathrm{SWIR}) /(\mathrm{NIR}+\mathrm{SWIR})
$$

Pre- and post-fire NBR images were next differenced for each Landsat scene pair to generate the Relative dNBR.

$$
\begin{aligned}
\operatorname{RdNBR}= & {[(\text { NBRpre-fire }- \text { NBRpost-fire })] / } \\
& \sqrt{\text { ABS (NBRpre-fire) }}
\end{aligned}
$$

RdNBR severity classes of low, moderate, and high potentially cover a range of -500 to +1200 over burned land surfaces. Positive RdNBR values represent a decrease in vegetation cover and a higher burn severity, while negative values would represent an increase in live vegetation cover following the fire event.

\section{Burn index estimation}

In July 2017, burned areas and adjacent unburned forest stands were surveyed along and within the boundaries of the Tozi-Spicer Creek Fire and the Blind River-Bering Creek Fires on either bank of the Yukon River near Tanana (Fig. 2). Following the Composite Burn Index (CBI) protocol from Key and Benson [20], as customized for forests of Alaska [3], we made ocular estimates at each soil sampling site of the degree of change caused by 2015 wildfire within five forest strata: (1) substrate layer, (2) low vegetation less than 1-m tall, (3) tall shrubs/sapling trees 1-2 m tall, (4) intermediate trees $2-8 \mathrm{~m}$ tall, and (5) large trees $>8 \mathrm{~m}$ tall. Within each stratum, four to five variables were scored to generate a CBI ranking between 0 and 3 for the level of burn severity. All live and dead plant species were noted and photographed at each forest site visited.

\section{Soil measurements and sampling}

At each sampling site near Tanana, the surface organic layer was excavated in July 2017 to create $30 \mathrm{~cm}$ depth soil pits. True color (RGB) and thermal infra-red (TIR) images of all excavated soil pits were collected using a FLIR Series C2 hand-held camera (with an object range of -10 to $150{ }^{\circ} \mathrm{C}$ ), recording $320 \times 240$ pixels per image. All TIR image data was collected over short time window (mid-day hours of 10 a.m. to 2 p.m.) on 


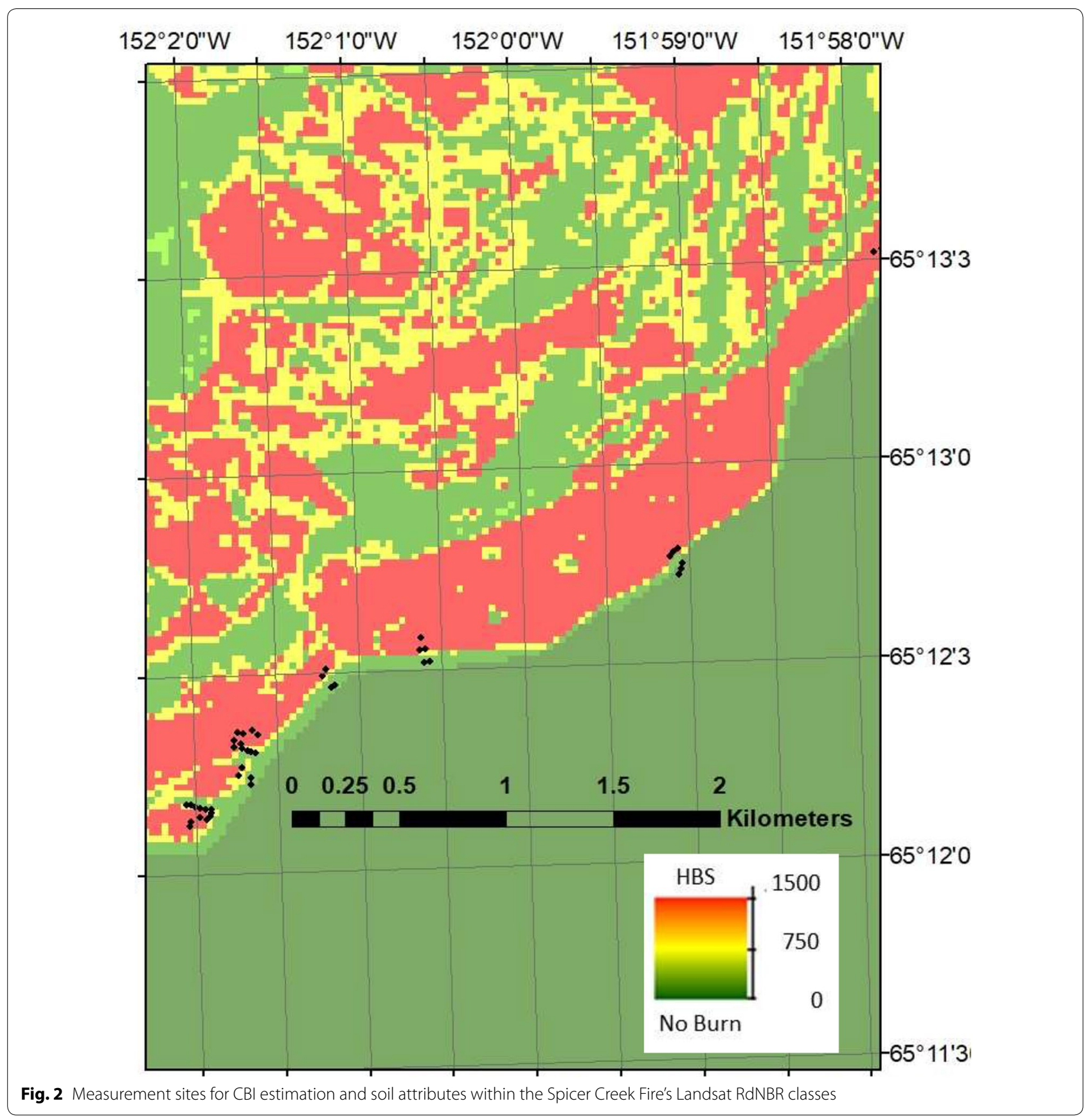

5 consecutive days in July 2017 during which air temperature was highly constant and no rainfall events occurred.

At least $500 \mathrm{~g}$ of mineral soil sample was collected, starting at $10 \mathrm{~cm}$ depth (below the bottom level of the surface organic layer) down to $30 \mathrm{~cm}$ mineral soil depth from each pit, sealed in ziplock plastic bags, and shipped to the Oregon State University Crop and Soil Science Central Analytical Laboratory for analysis of carbon and nitrogen content by the total elemental combustion technique. A total of 19 unburned and 19 burned forest soils were excavated to a depth of $30 \mathrm{~cm}$ in the soil pits and sampled in this manner.

To verify soil pit TIR imaging patterns with depth, soil temperature was measured using a ThermCo digital thermometer with a $7-\mathrm{cm}$ stainless steel probe inserted into the organic layer ground cover, and at 10 and $30 \mathrm{~cm}$ soil depths. 


\section{Statistical analysis}

Linear least squares regression was used to test for significant correlation relationships between burn severity attributes. Tests of statistical significance between unburned and burned site attributes were carried out using the two-sample Kolmogorov-Smirnov (K-S) test, a nonparametric method that compares the cumulative distributions of two data sets [21]. The $\mathrm{K}-\mathrm{S}$ difference test does not assume that data were sampled from Gaussian distributions (nor any other defined distributions), nor can its results be affected by changing data ranks or by numerical (e.g., logarithm) transformations. The K-S test reports the maximum difference between the two cumulative distributions, and calculates a probability $(p)$ value from that difference and the group sample sizes. It tests the null hypothesis that both groups were sampled from populations with identical distributions according to different medians, variances, or outliers. If the $\mathrm{K}-\mathrm{S} p$ value is small (i.e., $<0.05$ ), it can be concluded that the two groups were sampled from populations with significantly different distributions.

\section{Results}

\section{CBI versus RdNBR}

Field surveys across a total of 48 unburned and burned (in 2015) forest sites near Tanana showed that the measured CBI was significantly correlated (at $p<0.01$, $\left.R^{2}=0.85\right)$ with the Landsat RdNBR from both 2015 and 2016 post-fire images (Fig. 3). An observed CBI value of 3.0, indicating complete consumption of all pre-fire forest (strata) biomass during the 2015 fires, corresponded to a Landsat RdNBR value of about 1000 and the most extreme HBS post-fire conditions.

\section{Plant growth in HBS areas}

At all sites recorded with a CBI value greater than 2.0, there was no observed regrowth in July 2017 of any shrub or tree species that was observed growing in any

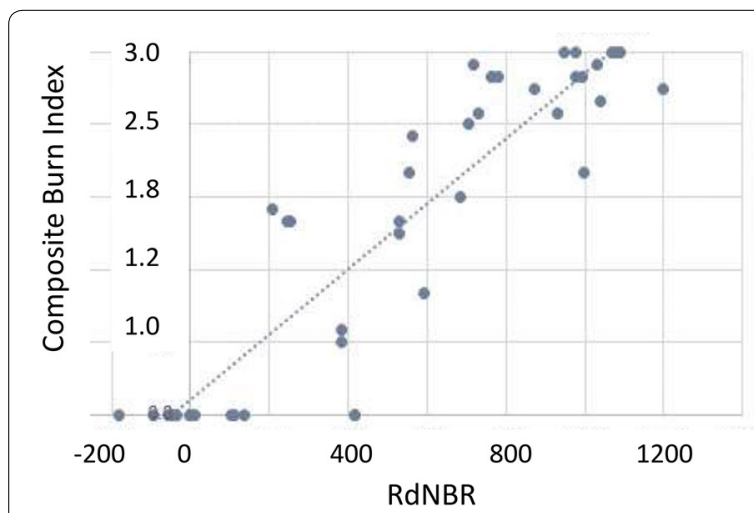

Fig. 3 Correlation of the Landsat RdNBR (from 2016) with CBI estimates for forest sites surveyed near Tanana in July 2017 the unburned spruce forest sites $(\mathrm{CBI}=0)$, as listed in the study area description above. At all HBS locations we surveyed, the substrate layer was comprised of entirely dead (charred blackened) moss and lichen cover. Occasional hummocks $50 \mathrm{~cm}$ deep (or deeper) and several meters in length of dead moss layer were encountered in transect crossings of these HBS areas. The low vegetation stratum $(<1-\mathrm{m}$ tall $)$ at all $\mathrm{HBS}$ areas visited was comprised of relatively sparse coverage of fireweed (Chamaenerion angustifolium), horsetails, and mixed grasses. Ground cover plant species commonly seen in unburned forest locations, but not seen regrowing in HBS locations in 2017, were bog blueberry (Vaccinium uliginosum) and highbush cranberry (Vibernum edule).

\section{Differences in surface organic layer thickness and temperature}

Visual evaluation of paired (unburned and burned) true color photos of organic soil layer thickness revealed that severely burned forest sites (CBI > 2) had lost between 5 and $10 \mathrm{~cm}$ of the thick live moss and lichen cover observed at every unburned forest site surveyed in 2017. By comparisons of soil TIR temperature profiles, we measured a significant separation $(p<0.05)$ in averaged soil temperature profiles between unburned and severely burned forest sites $(\mathrm{CBI}>2)$, beginning around $14 \mathrm{~cm}$ soil depth (Fig. 4). The profile temperatures commonly stabilized at between 8 and $12{ }^{\circ} \mathrm{C}$ in HBS site soils below about $15 \mathrm{~cm}$ depth from the top of the remaining organic surface layer. In contrast, at unburned forest sites, measured TIR temperatures continued to decline gradually to below $0{ }^{\circ} \mathrm{C}$ at a typical soil depth of $25 \mathrm{~cm}$ from the top of the thick $(10-\mathrm{cm})$ intact organic surface layer of moss and lichen cover. Averages of pit profile data showed the higher temperatures of $5-8{ }^{\circ} \mathrm{C}$ at $30 \mathrm{~cm}$ depth in the HBS soil profiles, compared to consistently freezing temperatures measured at bottom of the 30- $\mathrm{cm}$ deep unburned site profiles.

These TIR imaging differences were confirmed by soil probe measurements, which showed that mean soil temperatures recorded at $10 \mathrm{~cm}$ depth were significantly greater $(p<0.001)$ in burned forest sites $(\mathrm{CBI}>2$, $\mathrm{n}=19)$ at $8.1{ }^{\circ} \mathrm{C}$ compared to unburned sites $(\mathrm{CBI}=0$, $\mathrm{n}=19$ ) with a mean value of $3.0^{\circ} \mathrm{C}$. Furthermore, mean soil temperatures recorded at $30 \mathrm{~cm}$ depth were significantly greater $(p<0.001)$ in burned forest sites $(\mathrm{CBI}>2)$ at $6.5{ }^{\circ} \mathrm{C}$ compared to unburned sites $(\mathrm{CBI}=0)$ with a mean value of $0{ }^{\circ} \mathrm{C}$.

\section{Differences in mineral soil carbon and nitrogen}

There was a significant difference $(p<0.05)$ in both surface mineral soil carbon and nitrogen content from 


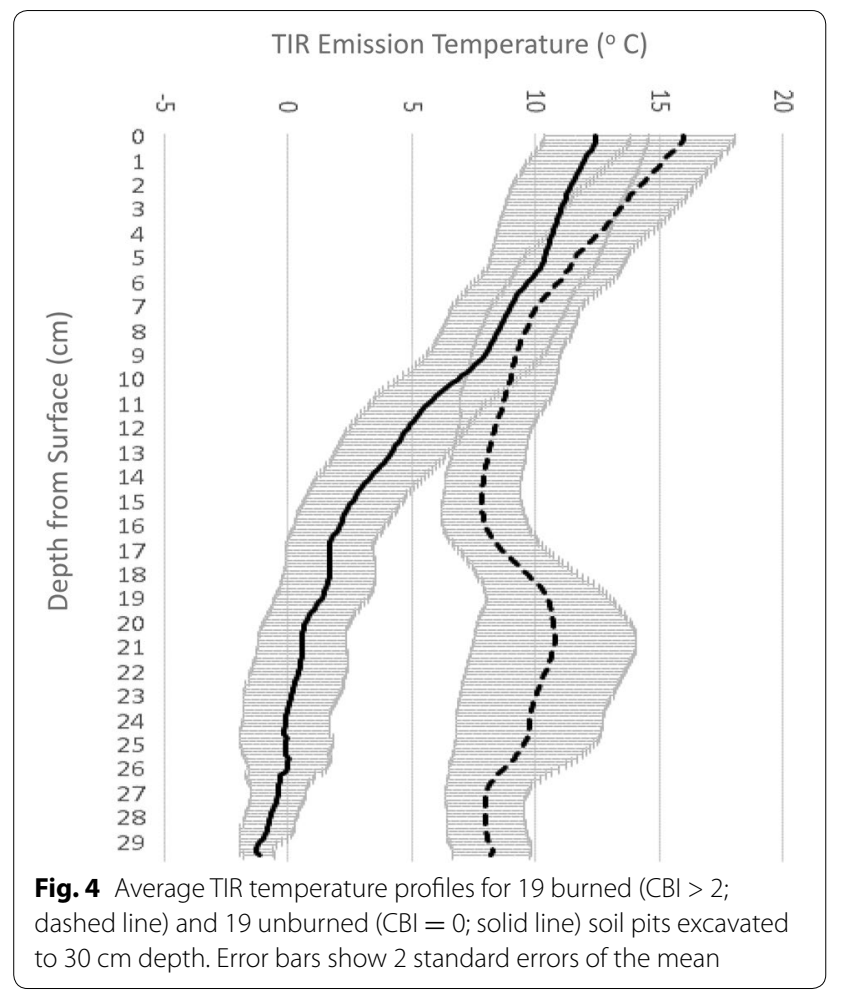

unburned $(\mathrm{CBI}=0)$ and severely burned $(\mathrm{CBI}>2)$ forest sites near Tanana Alaska in July 2017 (Table 2). On average, there was a $65 \%$ reduction in soil carbon content and a $58 \%$ reduction in soil nitrogen content in severely burned sample sites compared to soil mineral samples from nearby unburned spruce forests. This resulted in the soil mineral C:N ratio decreasing by $20 \%$ in severely burned sample sites, due to the higher relative loss of soil carbon over soil nitrogen during or after the 2015 wildfires.

These measured fractional changes in soil $\mathrm{C}$ and $\mathrm{N}$ content of unburned and severely burned forests, adjusted by previous soil bulk density measurements from forest sites across Alaska (Table 3), resulted in average estimated loss of carbon since the 2015 wildfires equal to $15.6 \mathrm{~kg} \mathrm{C} \mathrm{m}{ }^{-2}$ from the mineral soil layer (sampled to $30-\mathrm{cm}$ depth). Carbon loss from the severe burning of live moss and the surface organic layers together were estimated at slightly more than $9 \mathrm{~kg} \mathrm{C} \mathrm{m}^{-2}$.

\section{Landsat burn severity areas for 2015}

Compilation of burn severity class areas for 113 wildfires mapped in 2015 from the MTBS project (Fig. 1) showed a total of 1.64 million ha burned across the Yukon-Koyukuk region of Alaska (Table 4), with averages of 30 and $27 \%$ at MBS and HBS fraction per fire, respectively. Total regional 2015 burned areas were estimated at 0.47
Table 2 Surface mineral soil carbon and nitrogen content from unburned $(C B I=0)$ and severely burned $(C B I>2)$ forest sites in $\mathbf{2 0 1 5}$ near Tanana Alaska

\begin{tabular}{lccc}
\hline & $\begin{array}{l}\text { C (\% sample dry } \\
\text { weight) }\end{array}$ & $\begin{array}{l}\text { N (\% sample dry } \\
\text { weight) }\end{array}$ & C/N ratio \\
\hline Mean CBI = & 12.56 & 0.64 & 19.21 \\
Mean CBI > 2 & 4.38 & 0.27 & 15.39 \\
2SE CBI = 0 & 4.76 & 0.25 & 1.85 \\
2SE CBI > 2 & 1.88 & 0.11 & 1.15 \\
Min CBI = 0 & 1.14 & 0.15 & 7.60 \\
Min CBI > 2 & 0.90 & 0.09 & 10.00 \\
Max CBI = 0 & 37.74 & 1.93 & 25.06 \\
Max CBI > 2 & 18.45 & 1.08 & 18.38 \\
K-S test $p$ & $<0.01$ & $<0.05$ & $<0.01$ \\
\hline
\end{tabular}

2SE indicate two standard errors of the mean

million ha MBS and 0.52 million ha HBS. Among the largest of the 2015 fires, in excess of 70,000 ha total area burned, were the Middle Yukon and Tanana Area Fires, the latter of which was mapped at $48 \%$ HBS area. The majority of these largest Alaska forest wildfires in 2015 were located between $64.5^{\circ}$ and $66^{\circ} \mathrm{N}$ latitude.

\section{Regional carbon losses from 2015 wildfires}

Based on the total MBS and HBS forest areas consumed in 2015 across the Yukon-Koyukuk region (from Table 3), plus the organic layer carbon fractions consumed in MBS and HBS areas from [26], and the estimated loss of carbon since the 2015 wildfires from the mineral soil layer and the live moss and surface organic layers (from Table 2), it was determined that $154 \mathrm{Tg} \mathrm{C}$ were lost following the wildfires in interior Alaska in 2015. Mineral soil losses (and surface organic layer carbon emission totals from combustion) did not include the emission from combustion of aboveground forest biomass, which, based on average area-based carbon losses reported by Tan et al. [26] of $2.23 \mathrm{~kg} \mathrm{C} \mathrm{m}^{-2}$, would have added 8.7 Tg C in Alaska wildfire emissions in 2015.

\section{Discussion}

The exceptionally warm and dry conditions leading up to the summer of 2015 were followed by the largest wildfires recorded in decades in interior Alaska. Our estimate of the depth to which MBS and HBS wildfires had burned into and completely consumed surface organic moss layers during the 2015 Tanana fires was between 5 and $10 \mathrm{~cm}$. This burn depth estimate was confirmed using the relationship reported by Harden et al. [11], that for every centimeter of organic mat thickness in boreal forests, soil temperature under the organic layer remained about $0.5{ }^{\circ} \mathrm{C}$ cooler during summer months. The difference 
Table 3 Live moss, surface organic layer, and soil carbon content (to $30 \mathrm{~cm}$ depth) estimated for unburned and severely burned (since 2015) forests near Tanana, based on previous bulk density measurements from forest sites across Alaska and percent mineral soil carbon changes from Table 1. Bulk density $\left(\mathrm{g} \mathrm{cm}^{-3}\right)$

\begin{tabular}{|c|c|c|c|c|c|c|c|c|}
\hline Horizon & Site 1 & Site 2a & Site $\mathbf{2 b}$ & Site 3 & Mean & $\mathrm{Kg} \mathrm{C} \mathrm{m}^{-2}$ unburned & $\mathrm{KgC} \mathrm{m}^{-2}$ burned & $\mathrm{Kg} \mathrm{C} \mathrm{m}^{-2}$ difference \\
\hline Moss & & & & 0.02 & 0.02 & 1.0 & 0.5 & $0.5^{\mathrm{a}}$ \\
\hline A & 0.40 & 0.30 & 0.50 & & 0.35 & 17.6 & 8.8 & $8.8^{\mathrm{a}}$ \\
\hline B & 0.75 & 0.52 & & & 0.64 & 23.9 & 8.3 & 15.6 \\
\hline
\end{tabular}

Bulk density measurements of surface organic layer (A) and mineral horizon (B)

Site 1 [5]

Site 2 [14]

Site $3[25]$

a Carbon difference between unburned and severely burned sites for live moss and A horizon was assumed to be $50 \%$ by weight [26]

(increase) we measured in average temperature at $10 \mathrm{~cm}$ soil depth between severely burned and unburned sites was $5{ }^{\circ} \mathrm{C}$, which, according to Harden et al. [11], would imply a loss of $10 \mathrm{~cm}$ in the organic moss layer thickness in severely burned $(\mathrm{CBI}>2)$ forest areas.

In severely burned forest sites, the complete consumption of the living moss organic layer was strongly associated with warming at the soil surface layer. Measurements showed that soil temperature to $30 \mathrm{~cm}$ depth was higher by $8-10{ }^{\circ} \mathrm{C}$ compared to unburned forest sites. Below $15 \mathrm{~cm}$ soil depth, the temperature of unburned sites dropped gradually to sub-zero $\left({ }^{\circ} \mathrm{C}\right)$ levels by $30 \mathrm{~cm}$ depth, while soil temperatures at burned sites remained above $5{ }^{\circ} \mathrm{C}$ to $30 \mathrm{~cm}$ depth. Our results were similar to those reported by Nossov et al. [24] for fire impacts on forested areas of Yukon Flats and the Yukon-Tanana Uplands-these burns caused a fivefold decrease in surface organic layer thickness, a doubling of water storage in the soil active layer, a doubling of thaw depth, and an increase in soil temperature at the surface (to $+2.1{ }^{\circ} \mathrm{C}$ ) and at $1 \mathrm{~m}$ depth (to $+0.4{ }^{\circ} \mathrm{C}$ ).

Nearly all of the HBS sites measured during our 2017 field surveys of the Tanana Area Fires had no live surface organic layers remaining. Intense fires during summer of 2015 consumed between 5 and $10 \mathrm{~cm}$ of the former live surface organic layer and left behind only a residual dead, charred moss and lichen cover about 3-5 cm deep that had little capacity to insulate the soil layers beneath. We observed that the blackened surface organic layer showed a tendency to be $2-4{ }^{\circ} \mathrm{C}$ warmer than the live moss layer under unburned spruce forest strata. These results are consistent with those of Jiang et al. [13] and Brown et al. [7], who reported that post-fire thickness of the soil organic layer and its impact on soil thermal conductivity was the most important factor determining post-fire soil temperatures and thaw depth.

Our total estimate of more than $160 \mathrm{Tg} \mathrm{C}$ emitted or lost since 2015 from wildfires in the Yukon-Koyukuk region of Alaska, which included the combined losses from aboveground biomass, surface organic layers, and mineral soil carbon pools, was higher than any previously published fire emission estimate for the forested regions of the state, as listed in Table 1. These previous carbon emission projections for Alaska have included measurements of aboveground (tree) biomass and changes in surface organic layer carbon pools, but have not included potential changes in mineral topsoil carbon pools in severely burned forests. Based on our mineral sampling data from forest soils near Tanana since the 2015 wildfires, which closely match potential carbon loss rates from other forest fire studies in Alaska (Table 5), the contribution of mineral soils to total ecosystem carbon emissions is the highest of the forest strata that are routinely measured.

Additional post-fire losses of between 10 and $15 \mathrm{~kg} \mathrm{C} \mathrm{m}^{-2}$ estimated in our study from thawed mineral soil pools appear to be roughly equivalent to the combined carbon emissions from burned aboveground biomass, live ground cover, and surface organic layers. This potential "mass wasting" and decomposition of the mineral layer (between 10 and $30 \mathrm{~cm}$ depth) soil carbon in severely burned areas of the Alaska interior could have occurred at any time between the end of the 2015 fires and the sampling period for this study of July 2017. The soil carbon losses measured in this study were not necessarily emitted during the short 2015 burn period, but instead were likely a consequence of the severe burn conditions that affected these soils following the direct fire emissions of carbon from the nearly complete combustion of aboveground (tree) biomass and in surface organic layers.

\section{Conclusions}

When wildfire areas have an overall percentage of MBS plus HBS areas higher than $60 \%$, as in 2015 for Interior Alaska, vast tracts of forest will be burned deeply into the 
Table 4 List of wildfires (greater than 10,000 ha) in the Yukon-Koyukuk region of Alaska in 2015

\begin{tabular}{|c|c|c|c|c|c|}
\hline Fire name & HUC4 name & Latitude & Hectares & $\%$ MBS & $\% \mathrm{HBS}$ \\
\hline Middle Yukon Fires & Nowitna River & 64.550 & 164,890 & 26 & 31 \\
\hline Tobatokh & Melozitna River & 65.760 & 89,117 & 18 & 49 \\
\hline Isahultila & Koyukuk Flats & 66.050 & 78,020 & 31 & 24 \\
\hline Holtnakatna & Dulbi River & 65.393 & 72,949 & 34 & 16 \\
\hline Tanana Area Fires & Ramparts to Ruby & 65.318 & 71,590 & 26 & 48 \\
\hline Rock & Koyukuk Flats & 66.044 & 57,895 & 31 & 45 \\
\hline Big Mud River 1 & Nowitna River & 64.670 & 57,069 & 30 & 44 \\
\hline Munsatli 2 & North Fork Kuskokwim River & 63.726 & 50,455 & 27 & 51 \\
\hline Blazo & Lower Innoko River & 63.479 & 50,175 & 38 & 9 \\
\hline Sushgitit Hills & Kanuti River & 66.051 & 47,887 & 24 & 48 \\
\hline Torment Creek & Kanuti River & 65.943 & 43,304 & 26 & 27 \\
\hline Sea & Nowitna River & 64.013 & 40,745 & 27 & 35 \\
\hline 3 day & Huslia River & 65.741 & 36,420 & 38 & 31 \\
\hline Hay Slough & Lower Tanana River & 65.034 & 34,887 & 29 & 20 \\
\hline Dulbi River & Dulbi River & 65.176 & 34,389 & 24 & 4 \\
\hline Blind River & Ramparts to Ruby & 65.109 & 34,087 & 32 & 32 \\
\hline Bering Creek & Ramparts to Ruby & 65.014 & 30,874 & 34 & 34 \\
\hline Rungun Creek & North Fork Kuskokwim River & 63.565 & 25,315 & 26 & 46 \\
\hline West Fork & Yukon Flats & 66.366 & 24,990 & 37 & 18 \\
\hline Iditarod River & Lower Innoko River & 62.549 & 24,644 & 21 & 5 \\
\hline Lloyd & Lower Tanana River & 64.668 & 22,890 & 24 & 56 \\
\hline Hardpac Creek & Yukon Flats & 66.904 & 20,974 & 21 & 53 \\
\hline Carlson Lake & Kantishna River & 63.764 & 19,502 & 45 & 8 \\
\hline Lower Reindeer Peak & Lower Innoko River & 62.481 & 19,265 & 24 & 21 \\
\hline Old Woman & Unalakleet & 64.043 & 18,812 & 32 & 35 \\
\hline Holonada & Tozitna River & 65.693 & 18,346 & 25 & 9 \\
\hline Stuyahok River & Anvik to Pilot Station & 62.251 & 18,308 & 32 & 21 \\
\hline Sethkokna & Nowitna River & 64.258 & 15,867 & 28 & 45 \\
\hline Yukon Creek & Galena & 64.300 & 15,794 & 29 & 6 \\
\hline Glacier & Melozitna River & 65.129 & 15,334 & 35 & 41 \\
\hline Harper Bend & Lower Tanana River & 64.938 & 15,215 & 29 & 44 \\
\hline Nulato & Galena & 64.818 & 14,458 & 33 & 26 \\
\hline Hamlin Creek & Ramparts & 65.924 & 14,095 & 26 & 49 \\
\hline Hickey Creek & Upper Innoko River & 62.600 & 13,635 & 23 & 54 \\
\hline Deepbank Creek & Farewell Lake & 62.886 & 13,386 & 39 & 48 \\
\hline Birch Creek 2 & Birch-Beaver Creeks & 65.372 & 13,257 & 28 & 8 \\
\hline Our Creek & Nowitna River & 63.964 & 12,796 & 29 & 48 \\
\hline Aggie Creek & Tolovana River & 65.247 & 12,498 & 21 & 24 \\
\hline Lawson & Nowitna River & 64.433 & 12,005 & 25 & 45 \\
\hline \multirow[t]{6}{*}{ Soda Creek } & North Fork Kuskokwim River & 63.246 & 10,424 & 21 & 53 \\
\hline & Sum for all 113 fires & & $1,635,293$ & & \\
\hline & Mean & & 14,472 & 30 & 27 \\
\hline & Standard deviation & & 23,101 & 9 & 18 \\
\hline & Maximum & & 164,890 & 57 & 65 \\
\hline & Minimum & & 453 & 10 & 1 \\
\hline
\end{tabular}


Table 5 Previous estimates of carbon emissions from forest fires in Alaska

\begin{tabular}{|c|c|c|c|c|c|}
\hline \multirow[t]{2}{*}{ Forest stratum } & \multirow[t]{2}{*}{$\mathrm{KgCm}-2$} & \multicolumn{3}{|c|}{$\begin{array}{l}\text { Fraction con- } \\
\text { sumed }\end{array}$} & \multirow[t]{2}{*}{ References } \\
\hline & & HBS & MBS & LBS & \\
\hline \multirow{3}{*}{$\begin{array}{l}\text { Aboveground } \\
\text { biomass }\end{array}$} & 2.23 & 0.42 & 0.34 & 0.13 & Tan et al. [26] \\
\hline & 2.00 & & & & Mack et al. [22] \\
\hline & 3.50 & & & & Kane and Vogel [16] \\
\hline \multirow{5}{*}{$\begin{array}{l}\text { Surface organic } \\
\text { layer }\end{array}$} & 5.85 & 0.59 & 0.39 & 0.23 & Tan et al. [26] \\
\hline & 6.15 & & & & Turetsky et al. [28] \\
\hline & 7.70 & & & & French et al. [10] \\
\hline & 4.28 & & & & Troth et al. [27] \\
\hline & 6.30 & & & & Kane and Vogel [16] \\
\hline Mineral topsoil & 10.23 & & & & Kane and Vogel [16 $]^{\mathrm{a}}$ \\
\hline
\end{tabular}

a Estimated based on normalization to soil carbon stocks from 100 years since last disturbance of the sites studied

surface organic layer. This sudden thinning or removal of the moss and soil organic layer will raise post-fire soil temperatures and increase thaw depths, leading to large losses of carbon and nitrogen from mineral soils layers that are much wetter and warmer than the unburned forests nearby. Our results from remote sensing and field measurements in unburned and nearby burned forest sites around Tanana were higher by an average of $8-10^{\circ} \mathrm{C}$ compared to unburned forest sites. Combined with nearly unprecedented forest areas severely burned in the Yukon-Koyukuk region of Alaska in 2015, updated total ecosystem fire-related losses of carbon to the atmosphere exceeded most previous estimates for the state by a factor of two, due mainly to the inclusion of potential "mass wasting or decomposition" of mineral soil carbon in the 2 years following these forest fires.

\section{Acknowledgements}

This work was supported by NASA Ames Research Center and the NASA ABoVE Logistics Office in Fairbanks, Alaska. Special thanks to Charles Hugny, Sarah Sackett, Cynthia Erickson, Will Putman and the Tanana Chiefs Conference, Gerald Nicholia and Shannon Erhart of the Tanana Tribal Council, all for assistance in access to field sites.

\section{Competing interests}

The author declares that he has no competing interests.

\section{Availability of data and materials}

Supporting data for this study can be accessed via an email request to the author at chris.potter@nasa.gov.

\section{Consent for publication}

Not applicable.

\section{Ethics approval and consent to participate} Not applicable.

\section{Funding}

Not applicable.

\section{Publisher's Note}

Springer Nature remains neutral with regard to jurisdictional claims in published maps and institutional affiliations.

Received: 19 October 2017 Accepted: 22 December 2017

Published online: 08 January 2018

\section{References}

1. Alaska Department of Natural Resources (ADNR), Yukon Tanana Area Plan, Division of Mining, Land and Water Resource Assessment and Development Section, Adopted January 2014, Anchorage, Alaska, 2014.

2. Alaska Interagency Coordination Center (AICC). Fires season weather summary. https://fire.ak.blm.gov/. Accessed 1 Aug 2017.

3. Alaska Interagency Fire Effects Task Group (FETG), 2007. Fire effects monitoring protocol (version 1.0). In: Allen J, Murphy K, Jandt R, editors. 2015. https://fire.ak.blm.gov. Accessed 1 Aug 2016.

4. Alaska Public Media. Five fires threaten Tanana on the Yukon. 2015. Accessed 30 Jul 2015.

5. Alexander EB. Bulk density equations for southern Alaska soils. Can J Soil Sci. 1989;69:177-80

6. Balshi MS, McGuire AD, Zhuang Q, Melillo J, Kicklighter DW, Kasischke E, Wirth C, Flannigan M, Harden J, Clein JS, Burnside TJ, McAllister J, Kurz WA Apps M, Shvidenko A. The role of historical fire disturbance in the carbon dynamics of the pan-boreal region: a process based analysis. J Geophys Res. 2007;112:G02029.

7. Brown DRN, Jorgenson MT, Kielland K, Verbyla DL, Praka A, Koch JC. Landscape effects of wildfire on permafrost distribution in interior Alaska derived from remote sensing. Remote Sens. 2016;8:654.

8. Brown RJE. Permafrost in Canada. Toronto: University of Toronto Press; 1970. p. 234.

9. Eidenshink J, Schwind B, Brewer K, Zhu Z, Quayle B, Howard S. A project for monitoring trends in burn severity. Fire Ecol Special Issue. 2007;3:3-21.

10. French N, Kasischke E, Turetsky M, De Groot W, Honrath R, Ottmar R. Carbon, trace gas, and particulate emissions from wildfires in the Boreal regions of North America. In: 16th annual international emission inventory conference emission inventories: "Integration, analysis, and communications" papers and presentations, Raleigh, May 14-17, 2007. https:// www3.epa.gov/ttnchie1/conference/ei16/.

11. Harden JW, Manies KL, Turetsky MR, Neff JC. Effects of wildfire and permafrost on soil organic matter and soil climate in interior Alaska. Glob Change Biol. 2006;12:2391-403.

12. InciWeb. Tanana area fires update. 2015. https://inciweb.nwcg.gov/ incident/article/4324/26203/. Accessed 30 Jul 2015.

13. Jiang $Y$, Rocha AV, O'Donnell JA, Drysdale JA, Rastetter EB, Shaver GR, Zhuang Q. Contrasting soil thermal responses to fire in Alaskan tundra and boreal forest. J Geophys Res Earth Surf. 2015;120:363-78.

14. Johnstone JF, Kasischke ES. Stand-level effects of soil burn severity on post-fire regeneration in recently burned black spruce forest. Can J For Res. 2005;35:2151-63.

15. Johnstone JF, Chapin FS, Hollingsworth TN, Mack MC, Romanovsky V, Turetsky M. Fire, climate change, and forest resilience in interior Alaska. Can J For Res. 2010;40:1302-12.

16. Kane ES, Vogel JG. Patterns of total ecosystem carbon storage with changes in soil temperature in boreal black spruce forests. Ecosystems. 2009;45:322-35.

17. Kasischke ES, Turetsky MR. Recent changes in the fire regime across the North American boreal region: spatial and temporal patterns of burning across Canada and Alaska. Geophys Res Lett. 2006;33:L09703.

18. Kasischke ES, Johnstone JF. Variation in postfire organic layer thickness in a black spruce forest complex in interior Alaska and its effects on soil temperature and moisture. Can J For Res. 2005:35:2164-77.

19. Kasischke ES, Verbyla DL, Rupp TS, McGuire AD, Murphy KA, Jandt R, Barnes JL, Hoy EE, Duffy PA, Calef M, Turetsky MR. Alaska's changing fire regime-implications for the vulnerability of its boreal forests. Can J For Res. 2010;40:1313-24.

20. Key CH, Benson NC. Landscape assessment. In: Lutes DC, Keane RE, Carati JF, Key CH, Benson NC, Gangi LJ, editors. 'FIREMON: Fire Effects Monitoring and Inventory System'. USDA Forest Service, Rocky Mountains research 
station general technical report RMRS-GTR-164-CD, 2006. p. LA-1-55, Fort Collins.

21. Lehmann, E. Nonparametrics: Statistical Methods Based on Ranks. New York: Springer; 2006

22. Mack MC, Treseder KK, Manies KL, Harden JW, Schuur EAG, Vogel JG, Randerson JT, Chapin FS III. Recovery of aboveground plant biomass and productivity after fire in mesic and dry black spruce forests of interior Alaska. Ecosystems. 2008;11:209-25.

23. McGuire AD, Genet H, He Y, Stackpoole S, D'Amore D, Rupp TS, Wylie BK, Zhou X, Zhu Z. Alaska carbon balance, Chap. 9. In: Zhu Z, McGuire AD, editors. Baseline and projected future carbon storage and greenhousegas fluxes in ecosystems of Alaska: U.S. Geological Survey Professional Paper 1826, 2016. https://doi.org/10.3133/pp1826.

24. Nossov DR, Jorgenson MT, Kielland K, Kanevskiy MZ. Edaphic and microclimatic controls over permafrost response to fire in interior Alaska. Environ Res Lett. 2013;8:035013. https://doi. org/10.1088/1748-9326/8/3/035013.

25. O'Donnell JA, Romanovsky VE, Harden JW, McGuire AD. The effect of moisture content on the thermal conductivity of moss and organic soil horizons from black spruce ecosystems in interior Alaska. Soil Sci. 2009;174:646-51.

26. Tan Z, Tieszen LL, Zhu Z, Liu S, Howard SM. An estimate of carbon emissions from, wildfires across Alaskan Yukon River Basin. Carbon Balance Manag. 2004;2007(2):12

27. Troth JL, Deneke FJ, Brown LM. Upland aspen/birch and black spruce stands and their litter and soil properties in interior Alaska. For Sci. 1976;22:33-44.
28. Turetsky MR, Kane ES, Harden JW, Ottmar RD, Manies KL, Hoy E, Kasischke ES. Recent acceleration of biomass burning and carbon losses in Alaskan forests and peatlands. Nat Geosci. 2011;4:27-31.

29. United States Fish and Wildlife Service (USFWS). Fire management annual report, FY2015. 2015. https://www.fws.gov/fire/program_statistics/2015/.

30. USDA. Soil Survey of Upper Tanana Area, Alaska. United States Department of Agriculture (USDA), Natural Resources Conservation Service in cooperation with the University of Alaska Fairbanks, Agricultural and Forestry Experiment Station, and the State of Alaska Department of Natural Resources. 1999.

31. Veraverbeke $S$, Rogers BM, Randerson JT. Daily burned area and carbon emissions from boreal fires in Alaska. Biogeosciences. 2015;12:3579-601.

32. Viereck $L$. The effects of fire in black spruce ecosystems of Alaska and northern Canada. In: Wein RW, MacLean DA, editors. The role of fire in northern circumpolar ecosystems. Chichester: Wiley; 1983. p. 201-20.

33. Viereck LA, Dyrness CT, Batten AR, Wenzlick KJ. The Alaska vegetation classification. Portland: United States Department of Agriculture, Forest Service, Pacific Northwest Research Station; 1992.

34. Zhu Z, McGuire AD, editors. Baseline and projected future carbon storage and greenhouse-gas fluxes in ecosystems of Alaska: U.S. Geological Survey Professional Paper 1826, 2016. https://doi.org/10.3133/pp1826.

35. Zhuang Q, Melillo JM, McGuire AD, Kicklighter DW, Prinn RG, Steudler PA, Felzer BS, Hu S. Net emissions of $\mathrm{CH}_{4}$ and $\mathrm{CO}_{2}$ in Alaska: implications for the region's greenhouse gas budget. Ecol Appl. 2007;17:203-12.

\section{Submit your manuscript to a SpringerOpen ${ }^{\circ}$ journal and benefit from:}

- Convenient online submission

$\checkmark$ Rigorous peer review

- Open access: articles freely available online

- High visibility within the field

- Retaining the copyright to your article

Submit your next manuscript at $\boldsymbol{\nabla}$ springeropen.com 